\title{
Modelling algal blooms in the Dutch coastal waters by integrated numerical and fuzzy cellular automata approaches
}

\author{
Qiuwen Chen ${ }^{a, b, *}$, Arthur E. Mynett ${ }^{b}$ \\ a Research Center for Eco-Environmental Sciences, Chinese Academy of Sciences, Shuangqinglu 18, Haidian District, \\ Beijing 100085, China \\ b WL/Delft Hydraulics, P.O. Box 177, 2600 MH, Delft, The Netherlands
}

\section{A R T I C L E I N F O}

\section{Article history:}

Received 23 June 2005

Received in revised form

27 May 2006

Accepted 16 June 2006

Published on line 14 August 2006

\section{Keywords:}

Algal blooms

Dutch coastal waters

Cellular automata

Fuzzy logic

Delft3D-WAQ

\begin{abstract}
A B S T R A C T
In this paper, an integrated numerical and fuzzy cellular automata model was developed to predict possible algal blooms in Dutch coastal waters basing on the irradiance, nutrients and neighbourhood conditions. The numerical module used Delft3D-WAQ to compute the abiotic conditions, and fuzzy cellular automata approach was applied to predict the algal biomass that was indicated by chlorophyll a concentration. The simulated results of year 1995 were compared with that from BLOOM II model, and the advantages, disadvantages as well as future improvement were presented. In general, through this study, it is seen that the integrated modelling deserves more research inputs because: (1) the hydrodynamic processes and nutrients concentrations can be simulated in details by numerical method; (2) the irregular and sparse water quality and biological data, and the empirical knowledge from experts can be explored by the fuzzy logic technique; (3) the spatial heterogeneity, local interactions and the emerge of patchiness could be well captured through the cellular automata paradigm.
\end{abstract}

(c) 2006 Elsevier B.V. All rights reserved.

\section{Introduction}

The Dutch coast receives the drainage from the river Rhine and Meuse and is one of the most productive fishing areas in the world. In the past 20-50 years, the increase of nutrients discharged by the rivers has led to the eutrophication of the coastal zones (Nelissen and Stefels, 1988; Schaub and Gieskes, 1991; Klein and Buuren, 1992; Peperzak et al., 1998). Spring algal blooms, which is defined as chlorophyll a concentration $\geq 30 \mu \mathrm{g} / \mathrm{l}$, occur frequently in Dutch coastal waters (Veldhuis et al., 1986; Colijn and Cadée, 2003) that are usually dominated by diatoms and followed by Phaeocystis globosa (P. globoso). They mostly onset very locally and show strong patchy dynamics, e.g. in the Noordwijk transect and the Wadden Sea. The bloom of $P$. globosa (defined as cell number $\geq 1$ million $\mathrm{l}^{-1}$ ) is usually non-toxic, but it could be harmful. It is presumed to produce thick foam under certain onland wind condition, which gives terrible look and evil smell. It is also speculated that the consequent mineralization of settled P. globosa leads to anoxia and massive bivalve mortality (Peperzak, 2002).

Algal bloom is a complicated phenomenon where hydrodynamics, chemical and biological processes are involved. Modelling of algal blooms is an important subject, but it is also challenging due to the complexity of aquatic ecosystem, insufficient knowledge of the detailed processes and mechanism involved and shortage of high quality data. Some of the processes such as hydrodynamic can be investigated in detail, while there are still a lot of mechanisms remaining unclear.

* Corresponding author. Tel.: +8610 62849326; fax: +861062849326.

E-mail address: qiuwen.chen@wldelft.nl (Q. Chen). 
Besides, the water quality and biological data are usually spare and uncertain for detailed analysis (Chen and Mynett, 2003a).

In the last decade, a number of studies have been conducted in this area (Cadée, 1982, 1991; Lancelot et al., 1987; Lancelot, 1990; Gieskes and Schaub, 1990; Escaravage et al., 1995; Brussaard et al., 1995; Cadée and Hegeman, 2002; Peperzak, 1993, 2002) and some numerical models had been set up to simulate the water quality and eutrophication (Postma et al., 1987; Los and Brinkman, 1988; Van Pagee et al., 1988; Villars, 1997; Huthnance, 1997; Moll and Radach, 2003). These numerical models are mainly based on detail description of physical processes and usually have many parameters for calibration. There are also some other types of models developed for the studied area. Blauw et al. (2002), Chen et al. (2002a) and Chen and Mynett (2004) developed fuzzy logic models for forecasting algal blooms in the Dutch coast under the European Commission HABES project. These fuzzy rule-based models are able to combine the empirical knowledge on algal bloom mechanism and the limited data from observations. They do not need intensive numerical simulations and are advantageous when quick and qualitative results (bloom or not bloom) are of interests. Chen and Mynett (2003a) also applied decision trees and piecewise regression approach to predicting P. globosa blooms in the area. Theses models are either completely deductive or completely inductive, and the modelling of ecological processes are usually separated from the simulations of the hydrodynamics (Huthnance, 1997; Blauw et al., 2002; Chen, 2004).

However, it has been widely recognised that the underlying physical and (bio)chemical processes are essential to the initiation and species composition of algal blooms (Franks, 1997; Anderson, 2002). The performance of algal bloom models is still restricted by the insufficient ability to integrate both the biological and the underlying physical processes (Donaghay and Osborn, 1997; Verkhozina et al., 2000) despite large efforts in the past years. In particular, the strong patchy dynamics that are mainly resulted from spatial heterogeneity and local interactions are absent in most conventional models. Therefore, reliable models to predict initiation, transport and persistence of algal blooms have yet to be well established (Recknagel et al., 1994, 1995; Recknagel, 1997; Chapra, 1998; Anderson, 2002; Chen, 2004).

In this research, an integrated numerical and fuzzy cellular automata model was developed to predict phytoplankton biomass in the Dutch coastal waters. The numerical Delft3DWAQ (water quality module) simulated the hydrodynamics, water column irradiance, nitrate and phosphates concentrations with the inputs from the River Rhine. The fuzzy logic module was transferred from the one that was developed on the basis of the Noordwijk 2 data (Chen and Mynett, 2004), and was used here to predict algal biomass concentrations on the basis of the computed abiotic factors from Delft3D-WAQ. In order to take into account the spatial heterogeneity and capture the patchiness of the blooms, cellular automata paradigm was implemented in the developed model.

The simulated results of year 1995 were analysed and then compared with that from the BLOOM II model. The advantages, disadvantages as well as future improvements were also discussed based on the evaluations.

\section{Materials and models}

\subsection{Study area and data}

The study focused on the near shore area of the Dutch coast (Fig. 1). About $80 \%$ of the total river inflow entering the North Sea from The Netherlands comes from the rivers Rhine and Meuse via the New Waterway and the Haringvliet. The influence of the freshwater extends to $70 \mathrm{~km}$ from the coast near Ter Heijde and Noordwijk.

Ten years of data (1991-2000) from the stations of Noordwijk transect were collected in this research for the calibration of Delft3D-WAQ and the setup of fuzzy logic module. The data contain 32 parameters, including physical parameters such as wind, incident irradiance $\left(E_{0}\right)$, water temperature $(T), p H$, suspended solid (ss), salinity (sal); chemical parameters $\mathrm{NH}_{4}{ }^{+}$, $\mathrm{NO}_{2}{ }^{-}, \mathrm{NO}_{3}{ }^{-}, \mathrm{PO}_{3}{ }^{-}, \mathrm{SiO}_{2}$; and biological parameters such as the chlorophyll $a(\mathrm{Chl}-a)$ and $P$. globosa concentrations. The sampling frequency from March to September is mostly once a week. From October to February, it is at least once a month. Because of the variation of sampling frequency, only the data from March to September of each year are used in the study. Linear interpolations are used when the sampling interval is larger than 10 days.

A summary of the important parameters of the data set is given in Table 1 . The algal blooms usually occur between

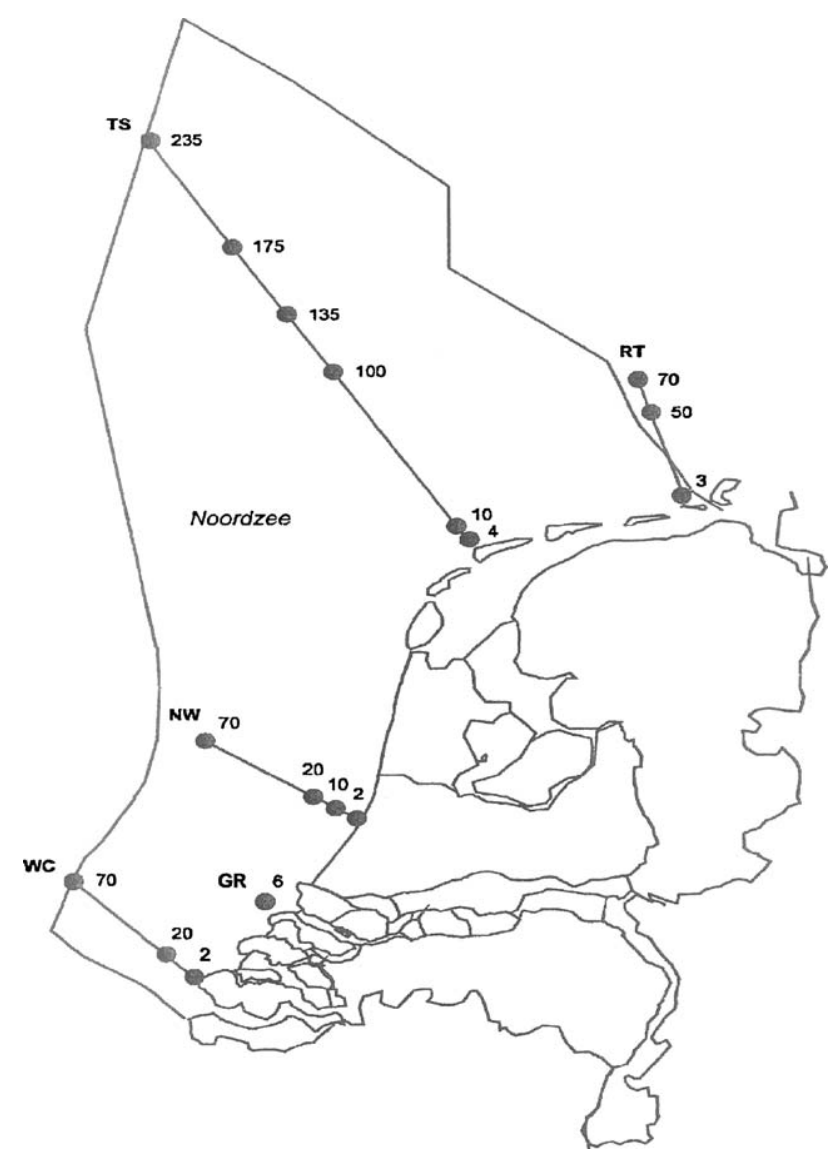

Fig. 1 - Dutch coast and the monitoring stations (Ref. Peperzak, 2002). 


\begin{tabular}{|c|c|c|c|c|c|c|c|c|}
\hline Parameters & Chl-a ( $\mu g / l)$ & $\mathrm{NO}_{3}{ }^{-1}(\mathrm{mg} / \mathrm{l})$ & $\mathrm{PO}_{4}{ }^{-3}(\mathrm{mg} / \mathrm{l})$ & $\mathrm{N} / \mathrm{P}$ ratio & Sal (psu) & $\mathrm{pH}$ & $\mathrm{T}\left({ }^{\circ} \mathrm{C}\right)$ & $\mathrm{I}_{0}\left(\mathrm{Wh} \mathrm{m}^{-2}\right.$ day $\left.^{-1}\right)$ \\
\hline Minimum & 0.1 & 0.007 & 0 & 2.40 & 28 & 7.8 & 5 & 132 \\
\hline Maximum & 90.2 & 1.246 & 0.073 & 439.4 & 32.5 & 8.8 & 22 & 1700 \\
\hline
\end{tabular}

April and June, except in 1994 when there was a second peak in August. In May 1995, there was an extraordinary peak with the Chl-a concentration of $90.2 \mu \mathrm{g} / \mathrm{l}$. The N/P ratios are between 2.4 and 44; therefore, it is not solely limited by phosphorus. The salinity was between 28.0 and 32.5 psu and was tested to have little effect on the algae development (Peperzak, 2002). Ploug et al. (1999) reported that the growth of Phaeocystis stops when the introcolonial $\mathrm{pH}$ is higher than 9.1. However, the measured $\mathrm{pH}$ values were between 7.8 and 8.8. The water temperature was between 5 and $22{ }^{\circ} \mathrm{C}$ that is in the range of temperature tolerance. The discharge from River Rhine at Maasluis station is between -2744 and $4649 \mathrm{~m}^{3} / \mathrm{s}$, with a mean of $1382 \mathrm{~m}^{3} / \mathrm{s}$. According to Peperzak (1993), the photosynthetically active radiation $\left(I_{0}\right)$ at the surface can be approximated by Eq. (1). The maximum $\mathrm{I}_{0}$ is $1700 \mathrm{~W} \mathrm{~h} \mathrm{~m}^{-2} \mathrm{day}^{-1}$, viz. lower than the photoinhibition value.

$I_{0}=0.45 \times E_{0}$

\subsection{Methodologies}

Delft3D-WAQ is a well established three-dimensional hydrodynamic and water quality model which is widely used around the world. In particular, it has long term application and intensive calibration in the Dutch coast (Peeters et al., 1995; De Vries et al., 1998).

Fuzzy logic (FL) has proved a useful and practical technique for modelling complex phenomena that may not yet be fully understood (Czogala and Leski, 2000; Lin et al., 2001), owing to the ability to deal with imprecise, uncertain or ambiguous data or relationships among data sets (Metternicht, 2001). A fuzzy inference system consists of three major components that are fuzzy set, membership functions and logic operators. The development of a fuzzy based model involves: (1) determination of model structure, i.e. input and output variables; (2) construction of appropriate membership functions; (3) formulation of appropriate linguistic rules. FL has been applied to algal blooms modelling in many cases (Los and Vonk, 1996; Shen and Chouchoulas, 2001), and was particularly facilitated by the HABES project (Blauw et al., 2002; Chen and Mynett, 2004).

Cellular automata constitute a mathematical system, in which many simple components interact locally to produce globally complicated patterns of behaviour. A cellular automata system usually consists of a regular lattice of sites (cells or automaton). Each site has some properties that are updated in discrete time steps according to local evolution rules $\phi$, which are functions of the states of cell itself and its neighbours. Cellular automata approach has been widely used in ecological modelling, including competitive growth and succession of underwater macrophytes (Wortmann et al.,
1997; Chen et al., 2002b), population dynamics of animals (Wootton, 2001; Chen and Mynett, 2003b). In the model presented in this paper, fuzzy cellular automata approach which has been explored by Wu (1996), Mielke and Pandey (1998) and Chen (2004) was introduced, where the local evolution rules $\phi$ are defined by fuzzy logic.

\subsection{Model setup}

Curvilinear grid is used for the computation in the Delft3DWAQ and there are totally 1157 computation cells for the studied area (Fig. 2). The modelling of nitrate and phosphate used numerical methods, and were realised through the processes library configuration tool (PLCT) of the Delft3D-WAQ. For nitrate, the mineralization, nitrification and denitrification processes are included. For phosphate, the adsorption-desorption processes are also involved except the mineralization, which are largely affected by the oxidation-reduction conditions. Major relevant parameters for nitrate and ortho-phosphate computation are listed in Table 2 . The boundary conditions are provided by the monitored time series data at the stations (Fig. 1), and the initial conditions were configured through linear interpolation of the monitored data.

The transport of the nutrients was then described through a three-dimensional advection-diffusion equation, where $S(C$, $t)$ is the source term from the river inflow that is given by the time series data at station Massluis, and $f_{R}(C, t)$ is reaction

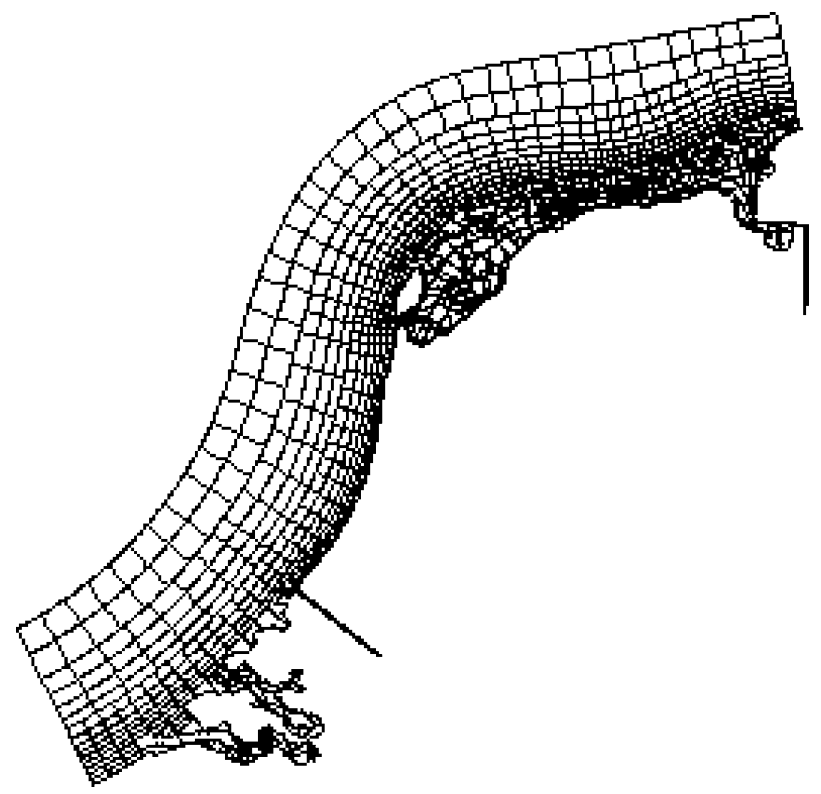

Fig. 2 - The curvilinear computation grid of studied area, totally 1157 computation cells. 
Table 2 - Major relevant parameters for nitrate and ortho-phosphate computation

\begin{tabular}{llll} 
Nitrate & & \multicolumn{2}{c}{ Ortho-phosphate } \\
\hline First order kinetic denitrification rate in sediment & 0.1 mol day $^{-1}$ & Adsorption rate & 1.0 day $^{-1}$ \\
First order kinetic denitrification rate in water & 0.1 day $^{-1}$ & First order kinetic desorption rate $^{-1}$ & 0.01 day $^{-1}$ \\
First order kinetic nitrification rate & 0.1 day $^{-1}$ & Mineralization rate in sediment $^{-1}$ & 0.03 day $^{-1}$
\end{tabular}
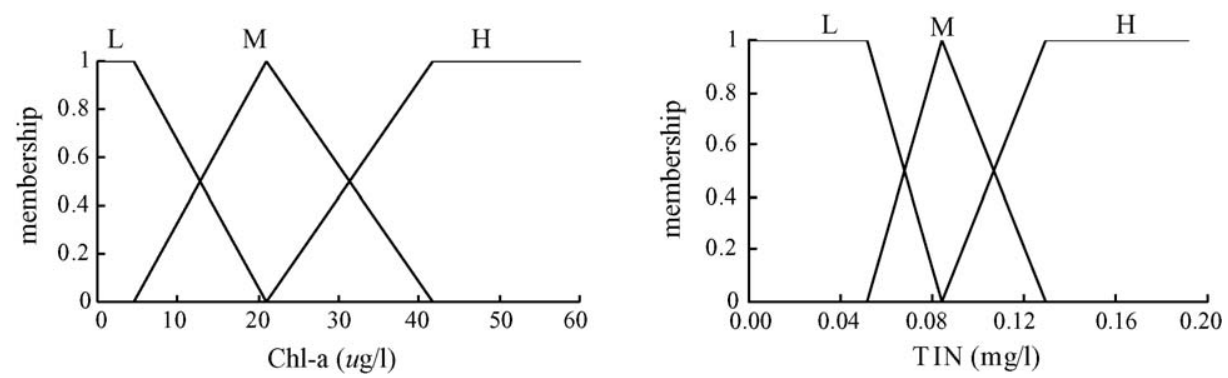

Fig. 3 - Membership functions of model variables and output (left: TIN; right: Chl-a).

terms.

$$
\begin{aligned}
\frac{\partial C}{\partial t}= & \frac{\partial}{\partial x}\left(D_{x} \frac{\partial C}{\partial x}-u_{x} C\right)+\frac{\partial}{\partial y}\left(D_{y} \frac{\partial C}{\partial y}-u_{y} C\right) \\
& +\frac{\partial}{\partial z}\left(D_{z} \frac{\partial C}{\partial z}-u_{z} C\right)+S(C, t)+f_{R}(C, t)
\end{aligned}
$$

The water column irradiance was calculated according to Lamber-Beer law, where $I_{0}$ is the irradiance at surface and $K_{d}$ is light attenuation coefficient.

$I(z)=I_{0} e^{-K_{d} z}$

The extinction is mainly contributed by water body (background attenuation), suspended solids (ss), salts (sal), and phytoplankton (Chl-a), and can usually be approximated by a regression:

$K_{d}=a+b \times s s+c \times s a l+d \times C h l-a$

Since Chl- $a$ is the parameter to be modelled, a simplified form of the formula applied in Chen and Mynett (2003a) was used in this paper

$K_{d}=1.91+0.045 \times \mathrm{ss}-0.058 \times \mathrm{sal}$

Because the studied area is usually well-mixed with only temporary and weak stratifications (De Kok et al., 2001), the mean water column irradiance is then used in the model, which is given by

$I_{m}=\frac{I_{0}\left(1-e^{-K_{d} Z}\right)}{K_{d} Z}$

The fuzzy logic model developed by Chen and Mynett (2004) was introduced to predict algal biomass on the basis of the calculated nutrient concentrations from the Delft3D-WAQ. The membership functions of Chl- $a$ and nitrate concentrations are shown in Fig. 3. The other variables include mean water column irradiance, water temperature and ortho-phosphate con-

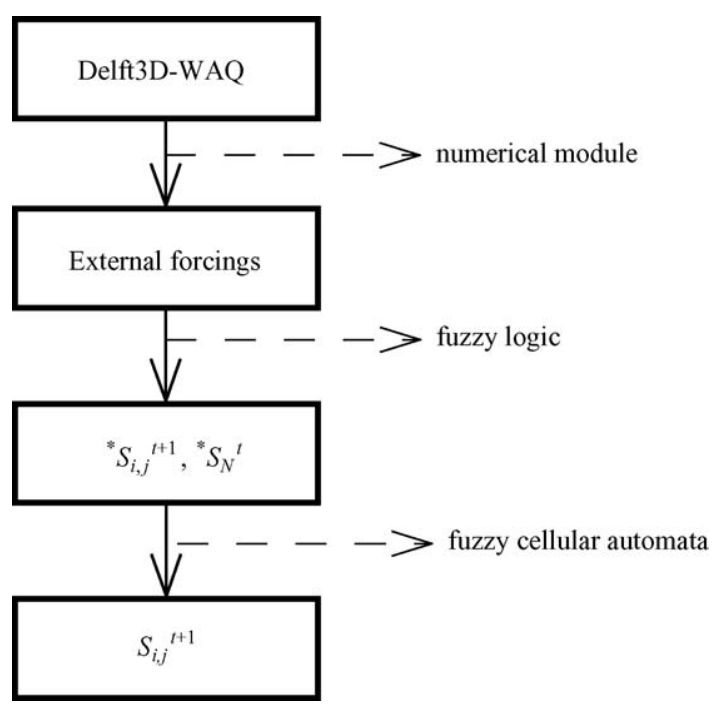

Fig. 4 - Sketch of the model framework.

Table 3 - Typical values to define the membership functions of the fuzzy logic module

\begin{tabular}{lccccc} 
& Very low & Low & Middle & High & Very high \\
\hline$I_{\mathrm{m}}\left(\mathrm{W} \mathrm{h} \mathrm{m}^{-2} \mathrm{day}^{-1}\right)$ & 178 & 302 & 441 & 589 & 770 \\
Nitrate $(\mathrm{mg} / \mathrm{l})$ & & 0.13 & 0.26 & 0.83 & 0.042 \\
Phosphate $(\mathrm{mg} / \mathrm{l})$ & & 0.007 & 0.017 & 41.8 \\
Chl- $a(\mu \mathrm{g} / \mathrm{l})$ & 4.5 & 21.1 & \\
\hline
\end{tabular}


centration (Table 3). Chlorophyll a concentration at last time step (Chl- $\left.a_{t-1}\right)$ is also used as the model input. There are totally 15 inference rules in the rule base that came either from ecologists' experience or from data leaning processes (Chen and Mynett, 2004; Chen, 2004).

The time step $(\Delta t)$ for hydrodynamics computation was $5 \mathrm{~min}$, and the simulation completed a full tidal cycle, which was then repeated for a year. The $\Delta t$ for nutrients simulation was $1 \mathrm{~h}$ in the Delft3D-WAQ and 7 days were used in the fuzzy logic model for algal biomass computation, therefore a time aggregation is made before initiating the water quality and fuzzy logic module. In this research, an arithmetic average was used to compute the weekly mean values.

The cellular automata module was directly implemented on the curvilinear grid, which of course did not strictly follow the original definition of CA where square grids are used. However, this approximation can be acceptable as the geometry of the cells does not have much difference in the nearest neighbours. Recently, a much finer grid is being implemented by using domain decomposition technique to improve the CA model accuracy. The Moore neighbourhood configuration was applied in the CA model and the local evolution rules were constructed by fuzzy logic technique that took a general formula as

$S_{i, j}^{t+1}=f\left({ }^{*} S_{i, j}^{t+1}, \sum * S_{N}^{t+1}\right)$

where $S_{i, j}^{t+1}$ is the state of cell $(i, j)$ at time step $t+1,{ }^{*} S_{i, j}^{t+1}$ the state of the cell $(i, j)$ at time step $t+1$ which is preliminarily computed by the fuzzy logic module, $\sum * S_{N}^{t+1}$ the preliminarily estimated states of the eight neighbouring cells, and $f$ are local fuzzy evolution rules. Thus, the model framework can be sketched as Fig. 4. In this study, the state $S$ takes a value of the fuzzy set of Chl-a concentration, given as $\mathrm{S}_{\mathrm{chl}-a}=(\mathrm{L}, \mathrm{M}, \mathrm{H})$.
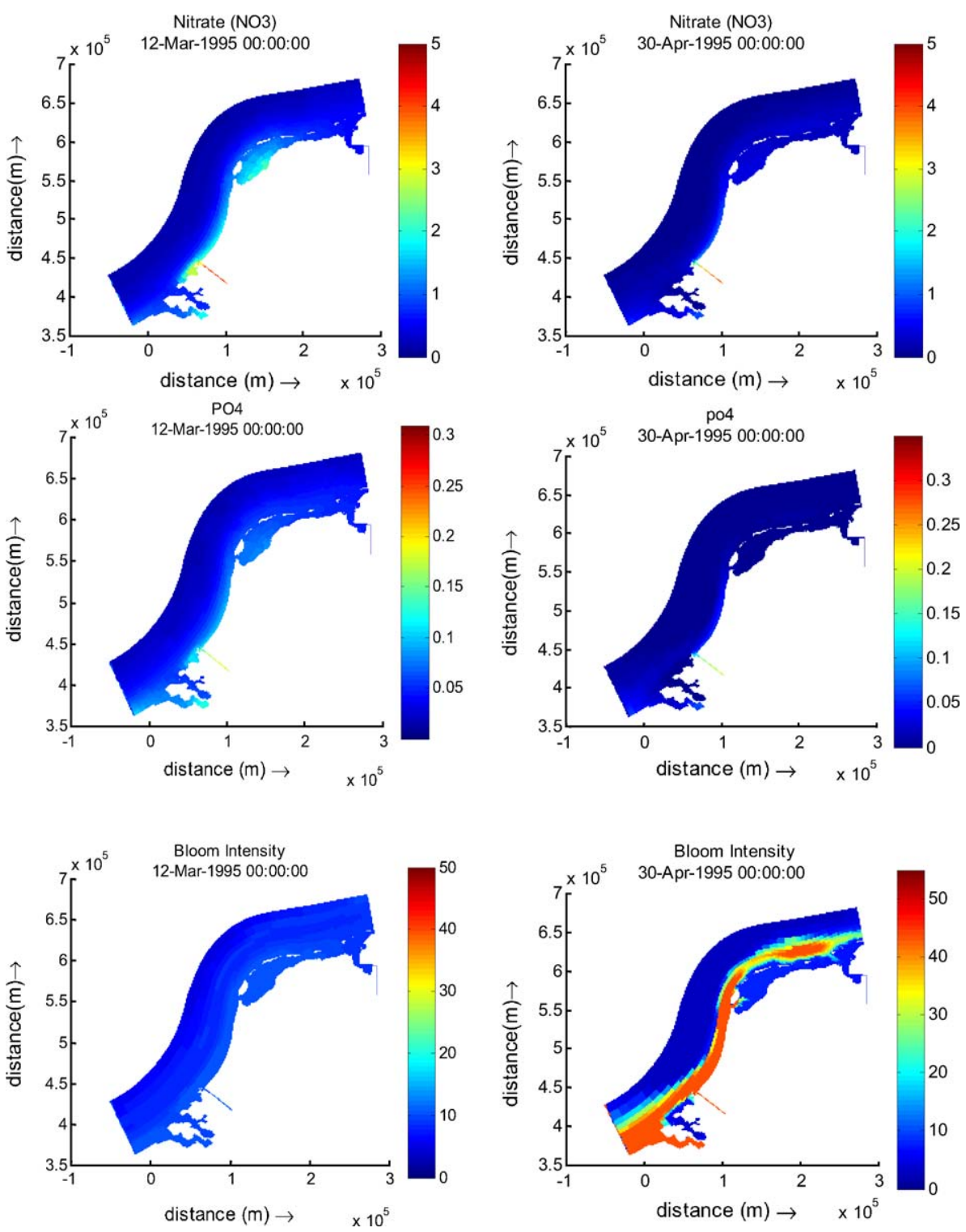

Fig. 5 - Concentrations of modelled inorganic nitrogen, inorganic phosphorus and algal biomass in winter period (left) and peak-bloom period (right). 
Supposing $* S_{i, j}^{t+1}=p$, the rules $f$ are defined as:

$S_{i, j}^{t+1}= \begin{cases}p & \text { if over 3 neighbours hold } * S_{\text {neighbour }}^{t+1}=p \\ 0.5(p+q) & \text { if over 3 neighbours hold } * S_{\text {neighbour }}^{t+1}=q\end{cases}$

$p, q \in \mathrm{S}_{\text {Chl-a }}$

In order to conduct a quantitative evaluation, the outputs were defuzzified by centre of gravity method, which is given by Eq. (9):

$D=\frac{\sum_{i=1}^{I} v_{i} M\left(B_{i}\right)}{\sum_{i=1}^{I} v_{i}}$

where $v_{i}$ is the fired degree of fuzzy rule $i$, and $M\left(B_{i}\right)$ is the fuzzy mean of the corresponding output fuzzy set of rule $i$, that is given by

$M(B)=\frac{\int_{-\infty}^{+\infty} x \mu_{B}(x) d x}{\int_{-\infty}^{+\infty} \mu_{B}(x) d x}$

in which $\mu_{B}$ is the membership function of fuzzy set $B$ on variable $x$.

\section{Results}

Some of the modelled results of nitrate, phosphate and chlorophyll a concentrations are given in Fig. 5 where figures at the right hand side are the results at peak-bloom period. In order to compare and evaluate the performance of the fuzzy cellular automata module, the BLOOM II model of Delft3D system was also used. The BLOOM II model applies optimization technique to obtain the maximum growth rate under given conditions through linear programming method (Los and Brinkman, 1988). The calculated chlorophyll a concentrations by BLOOM II model during the bloom period are presented in Fig. 6 .

To further evaluate the CA mode, the computed chlorophyll a concentrations from the CA and BLOOM II models as well as the observations along the Noordwijk transect, where the most consistent also the best data sets were available, during the bloom period in 1995 were compared in Table 4 and plotted in the Fig. 7. In addition, the time series of chlorophyll a concentrations at the station Noordwijk 10 in 1995 from observations, BLOOM II and CA model are presented in Fig. 8.

\section{Discussions}

It is seen from the modelled results (Fig. 5) that the concentrations of nitrate and phosphate are much higher in winter than in late spring and early summer. On the contrary, the algal biomass concentration is quite low in winter and becomes suddenly high in early summer.

The nutrients concentrations are higher in winter and early spring than in summer period because of: (1) the internal cycling from decomposition; (2) the main rainfall period being in winter and early spring which results in large external input by river discharge; and (3) the low uptake by phytoplankton due to light limiting growth.

In spatial domain, it is difficult to quantitatively compare the map of the modelled algae concentrations with the reality due to lack of observed maps. However, the modelled results showed certain spatial patchiness (Fig. 5). The nutrient concentrations are higher in the estuaries than in the coastal waters, hence the algal biomass which greatly depends on

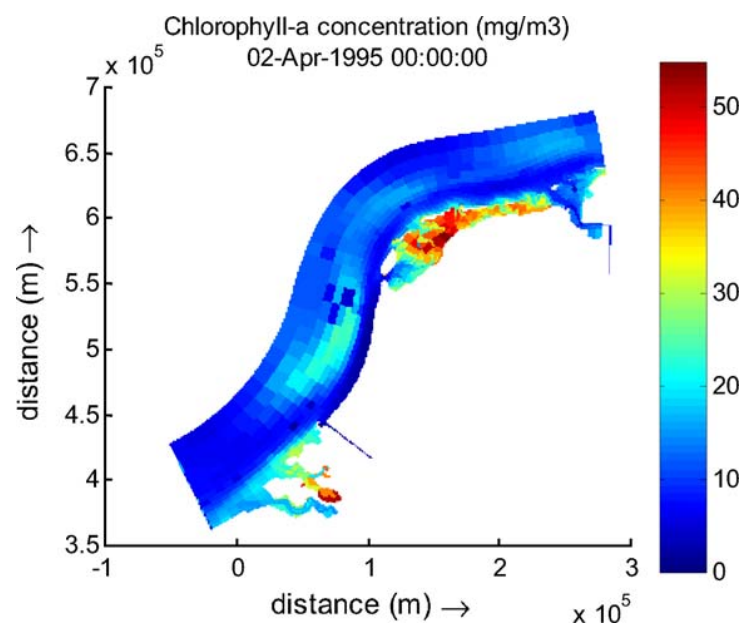

Fig. 6 - The first peak of chlorophyll a concentration modelled by BLOOM II of Delft3D system.

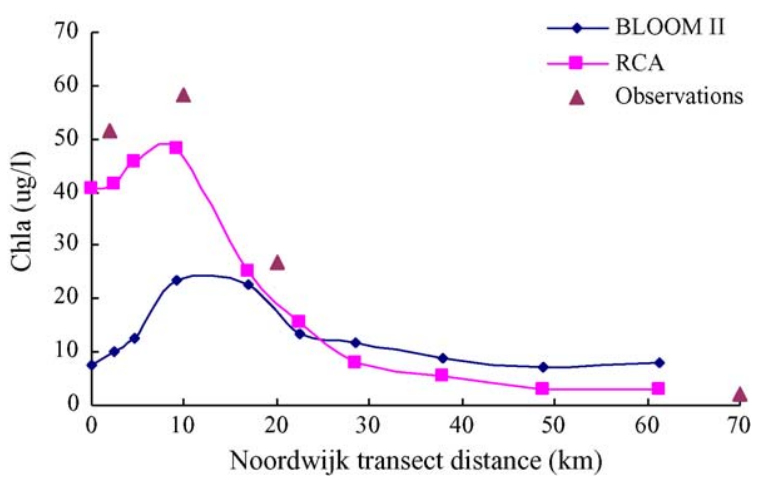

Fig. 7 - Plots of chlorophyll $a$ concentrations along the Noordwijk transect during bloom period in 1995 from observations (May 3), BLOOM II (April 2) and CA model (April 30).

Table 4 - Chlorophyll a concentrations from observations, BLOOM II and CA models along the Noordwijk transect during bloom period in 1995

\begin{tabular}{|c|c|c|c|c|c|c|c|c|c|c|c|c|}
\hline Off distance $(\mathrm{km})$ & 1 & 2 & 2.3 & 9.2 & 10 & 17 & 20 & 22.3 & 48.6 & 61 & 70 & Peak time \\
\hline Observation $(\mu \mathrm{g} / \mathrm{l})$ & & 51.6 & & & 58.2 & & 27 & & & & 1.94 & May 3 \\
\hline CA results $(\mu \mathrm{g} / \mathrm{l})$ & 40.56 & & 41.62 & 48.5 & & 25.2 & & 15.4 & 3.1 & 2.8 & & April 30 \\
\hline BLOOM II $(\mu \mathrm{g} / \mathrm{l})$ & 7.73 & & 10.2 & 23.62 & & 22.53 & & 13.27 & 7.15 & 8.1 & & April 2 \\
\hline
\end{tabular}




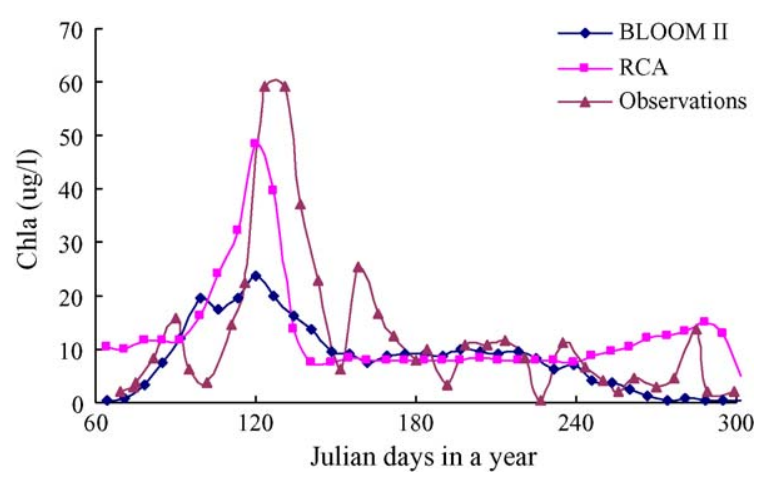

Fig. 8 - Time series plots of chlorophyll a concentrations at the station Noordwijk 10 in 1995 from observations, BLOOM II and CA model.

nutrient availability. The other observation is that the concentrations are higher in South-North direction (along the shore) than in East-West direction.

The nutrient concentrations are higher along the coast because the residual flow of river discharge is from the South to the North following the coastal line due to the effects of Coriolis force (Klein and Buuren, 1992). Therefore, the algal blooms centred on near shore area. It is also seen that the blooms are more severe near the Noordwijk transect and Wadden Sea area because of the discharge from the land.

At the bottom left (Fig. 5), there is a large area in red (high Chl- $a$ concentration), which is in fact an artefact. The cause is that the bottom-left boundary was placed over there in the model, and the cellular automata module largely propagated the boundary effects due to the coarse grid.

By examining the observations in 1995, the algal bloom initiated at the end of April, and the peak values appeared on May 3rd. From Table 4, the CA model well captured the bloom timing, but the BLOOM II had an obvious time difference. With respects to spatial patterns of the chlorophyll a concentration along the Noordwijk transect, the results of both CA and BLOOM II were similar to the observations (Fig. 7). This characteristic of spatial variations along the Noordwijk transect agrees well with the results of De Vries et al. (1998). However, it is clear to see that the CA model performs better than the BLOOM II by comparing the numerical values at the stations 2, 10, 20 and 70 in Table 4. From the time series plots of algal biomass concentration at the station Noordwijk 10 (Fig. 8), it is seen that the RCA model is able to simulate the temporal variations and performs better than the BLOOM II.

Compared to neural network algal bloom models that usually demand large data sets (Lee et al., 2003), the CA model developed in this study is not restricted by data requirements or is limited to some specific locations. The model integrates the previous fuzzy logic model (Chen and Mynett, 2004) with Delft3D-WAQ so that it can simulate the dynamics in a large area of the North Sea.

There are plenty of numerical models for simulations of primary production and algal blooms in the North Sea region such as the ECOPATH (Vasconcellos et al., 1997; Moll, 1998; Moll and Radach, 2003) and the MIRO (Lancelot et al., 2005). The developed CA model in this study also contains the capability for detailed simulations of hydrodynamics and water quality. However, the CA model introduces the fuzzy logic method in the biological part, which has advantages to explore the empirical knowledge and limited data. It also provides an alternative way to avoid the complicated formulation of detailed biological processes and the calibration of a large number of biological parameters. By comparing the results with the outputs which dropped out cellular automata component (Chen and Mynett, 2004), it demonstrated that the application of cellular automata paradigm enhanced the capture of the local patchiness, and such capability is not included in either the BLOOM II or MIRO or ECOPATH models.

The research presented in this paper is still ongoing, however, it is seen from the initial outputs that integration of numerical model with fuzzy cellular automata has potential perspectives; therefore, it deserves more research inputs. At present, a much finer grid has been implemented by the research team to improve the cellular automata performance and to reduce the artefact. Moreover, the fuzzy evolution rules of the cellular automata component are to be reiterated.

\section{Acknowledgements}

The first author appreciates the funds from the "100 Talents Program" of Chinese Academy of Sciences and supports from WL/delft hydraulics on this research. Thanks also go to Ir. Anouk Blauw and Ir. Leo Postma for the help on Delft3D-WAQ model, and the two anonymous reviewers for their valuable comments and very detailed corrections.

\section{REFERENCES}

Anderson, D.M., 2002. Monitoring and management of harmful algal blooms in coastal waters (keynote lectures). In: Tao, J. (Ed.), Proceedings of the 2nd International Workshop on Coastal Eutrophication. Hong Kong University/Tianjin University, China.

Blauw, A.N., Peperzak, L., Chen, Q., 2002. Modelling harmful algal blooms with fuzzy logic, with an example for Phaeocystis globosa in the Dutch coastal zone. In: Proceedings of the Xth International Conference on Harmful Algae, Florida, USA.

Brussaard, C.P.D., Riegman, R., Noordeloos, A.A.M., Cadée, G.C., Witte, H., Kop, A.J., Nieuwland, G., van Duyl, F.C., Bak, R.P.M., 1995. Effects of grazing, sedimentation and phytoplankton cell lysis on the structure of a coastal pelagic food web. Mar. Ecol. Prog. Ser. 123, 259-271.

Cadée, G.C., 1982. Tidal and seasonal variation in particulate and dissolved organic carbon in the western Dutch Wadden Sea and Marsdiep tidal inlet. Neth. J. Sea Res. 15 (2), 228-249.

Cadée, G.C., 1991. Phytoplankton variability in the Marsdiep, 1980-1989. In: Hydrobiological Variability in the ICES Area, 1980-1989, ICES Marine Science Symposia, vol. 195, pp. 213-222.

Cadée, G.C., Hegeman, J., 2002. Phytoplankton in the Marsdiep at the end of the 20th centry; 30 years monitoring biomass, primary production, and Phaeocystis blooms. J. Sea Res. 48, 97-110.

Chapra, S.C., 1998. Engineering approaches to algal modelling and management. In: Howard, A. (Ed.), Algal modeling: Processes \& Management, Proceedings of Conference in University of Reading. 
Chen, Q., Mynett, A.E., Blauw, A.N., 2002a. Fuzzy logic and artificial neural network modelling Phaeocystis in the North Sea. In: Falconer, R.A., Lin, B., Harris, E.L., Wilson, C.A.M.E. (Eds.), Proceedings of Hydroinformatics 2002, vol. 1. Cardiff, UK, pp. 722-728.

Chen, Q., Mynett, A.E., Minns, A.W., 2002b. Application of cellular automata to modelling competitive growth of two underwater species C. aspera and P. pectinatus in Lake Veluwe. Ecol. Model. 147, 253-265.

Chen, Q., Mynett, A.E., 2003a. Modelling Phaeocystis globosa bloom in Dutch coastal waters by decision trees and nonlinear piecewise regression. Ecol. Model. 176, 277-290.

Chen, Q., Mynett, A.E., 2003b. Effects of cell size and configuration in cellular automata based prey-predator modelling. Simul. Model. Pract. Theory 11, 609-625.

Chen, Q., Mynett, A.E., 2004. A robust fuzzy logic approach to modelling algal biomass. J. Hydraulics Res. 42, 303-309.

Chen, Q., 2004. Cellular Automata and Artificial Intelligence in Ecohydraulics Modelling. Taylor \& Francis Group plc, London, UK, ISBN 9058096963.

Colijn, F., Cadée, G.C., 2003. Is phytoplankton growth in the Wadden Sea light or nitrogen limited? J. Sea Res. 49, 83-93.

Czogala, E., Leski, J., 2000. Fuzzy and Neuro-Fuzzy Intelligence Systems. Physica-Verlag, ISBN 3-7908-1289-7.

De Kok, J.M., De Valk, C., Van Kester, J.H.Th.M., De Goede, E., Uittenbogaard, R.E., 2001. Salinity and temperature stratification in the Rhine plume. Estuaries, Coastal Shelf Sci. 53, 467-475.

De Vries, I., Duin, R.N.M., Peeters, J.C.H., Los, F.J., Bokhorst, M., Laane, R.P.M., 1998. Patterns and trends in nutrients and phytoplankton in Dutch coastal waters: comparisons of time-series analysis, ecological model simulation, and mesocosm experiments. ICES J. Mar. Sci. 55, 620-634.

Donaghay, P.L., Osborn, T.R., 1997. Toward a theory of biological-physical control of harmful algal bloom dynamics and impacts. Limnol. Oceanogr. 42, 1283-1296.

Escaravage, V., Peperzak, L., Prins, T.C., Peeters, J.C.H., Joordens, J.C.A., 1995. The development of a Phaeocystis bloom in a mesocosm experiment in relation to nutrients, irradiance and coexisting algae. Ophelia 42, 55-74.

Franks, P.J.S., 1997. Model of harmful algal blooms. Limnol. Oceanogr. 42, 1273-1282.

Gieskes, W.W.W., Schaub, B.E.M., 1990. Correlation of the seasonal and annual variation of phytoplankton biomass in Dutch coastal waters of the North Sea with Rhine river discharge. Coastal Estuarine Stud. 36, 311-320.

Huthnance, J.M., 1997. The PROFILE project: an overview. J. Mar. Syst. 12, 249-261.

Klein, A.W.O., Buuren, J.T., 1992. Eutrophication of the North Sea in the Dutch Coastal Zone 1976-1990. Report 09w-92.003, Rijkswaterstaat.

Lancelot, C., Billen, G., Sournia, A., Weisse, T., Colijn, F., Veldhuis, M.J., Davies, A., Wassman, P., 1987. Phaeocystis blooms and nutrient enrichment in the continental coastal zones of the North Sea. Ambio 16 (1), 38-46.

Lancelot, C., 1990. Phaeocystis blooms in the continental coastal area of the channel and the North Sea. Water Pollut. Res. Rep. $12,27-54$

Lancelot, C., Spitz, Y., Gypens, N., Ruddick, K., Becquevort, S., Rousseau, V., Lacroix, G., Billen, G., 2005. Modelling diatom and Phaeocystis blooms and nutrient cycles in the southern bight of the North Sea: the MIRO model. Mar. Ecol. Prog. Ser. 289, 63-78.

Lee, J.H.W., Huang, Y., Dickman, M., Jayawardena, A.W., 2003. Neural network modelling of coastal algal blooms. Ecol. Model. 159, 179-201.
Lin, W.S., Tsai, C.H., Liu, J.S., 2001. Robust neuro-fuzzy control of multivariable systems by tuning consequent membership functions. Fuzzy Sets Syst. 124, 181-195.

Los, F.J., Brinkman, J.J., 1988. Phytoplankton modelling by means of optimisation; a 10 year experience with BLOOM II. Verh. Int. Ver. Limnol. 23, 790-795.

Los, F.J., Vonk, M., 1996. Fuzzy logic in ecologische modellen. Delft Hydraulics Report T2029 (in Dutch).

Metternicht, G., 2001. Assessing temporal and spatial changes of salinity using fuzzy logic, remote sensing and GIS foundations of an expert system. Ecol. Model. 144, 163-179.

Mielke, A., Pandey, R.B., 1998. A computer simulation study of cell population in a fuzzy interaction model for mutating HIV. Physica A 251, 430-438.

Moll, A., 1998. Regional distribution of primary production in the North Sea simulated by a three-dimensional model. J. Mar. Syst. 16 (1-2), 151-170.

Moll, A., Radach, G., 2003. Review of three-dimensional ecological modelling related to the North Sea shelf system Part 1: models and theirs results. Prog. Oceanogr. 57, 175-217.

Nelissen, P.H.M., Stefels, J., 1988. Eutrophication in the North Sea, a literature survey. Netherlands Institute for Sea Research. Report 1988-4.

Peeters, J.C.H., Los, F.J., Jansen, R., Haas, H.A., Peperzak, L., de Vries, I., 1995. The oxygen dynamics of the Oyster Ground, North Sea. Impact of eutrophication and environmental conditions. Ophelia 42, 257-288.

Peperzak, L., 1993. Daily irradiance governs growth rate and colony formation of Phaeocystis (Prymnesiophyceae). J. Plankton Res. 15, 809-821.

Peperzak, L., Colijn, F., Gieskes, W.W.C., Peeters, J.C.H., 1998. Development of the diatom-Phaeocystis spring bloom in the Dutch coastal zone (North Sea): the silicon depletion versus the daily irradiance hypothesis. J. Plankton Res. 20, 517-537.

Peperzak, L., 2002. The wax and wane of Phaeocystis globosa blooms. Ph.D. dissertation. University of Groningen.

Ploug, H., Stolte, W., Jorgensen, B.B., 1999. Diffusive boundary layers of the colony-forming plankton alga, Phaeocystis sp.-implications for nutrient uptake and cellular growth. Limnol. Oceanogr. 44, 1959-1967.

Postma, L., De Kok, J.M., Markus, A.A., Van Pagee, J.A., 1987. Long term and seasonal water quality modelling of the North Sea and its coastal waters. International Council for the Exploration of the Sea (ICES) Hydrography Committee CMC, p. 39.

Recknagel, F., Petzoldt, T., Jaeke, O., Krusche, F., 1994. Hybrid expert system DELAQUA - a toolkit for water quality control of lakes and reservoirs. Ecol. Model. 71, 17-36.

Recknagel, F., French, M., Harkonen, P., Yabunaka, K., 1995. Artificial neural network approach for modelling and prediction of alga blooms. Ecol. Model. 96, 11-28.

Recknagel, F., 1997. ANNA-Artificial neural network model for predicting species abundance and succession of blue-green algae. Hydrobiologia 349, 47-57.

Schaub, B.E.M., Gieskes, W.W.C., 1991. Eutrophication of the North Sea: the relation between Rhine river discharge and chlorophyll-a concentration in Dutch coastal waters. In: Elliott, M., Ducrotoy, J.P. (Eds.), Estuaries and Coasts: Spatial and Temporal Interactions, pp. 85-90.

Shen, Q., Chouchoulas, A., 2001. FuREAP: a fuzzy-rough estimator of algae populations. Artif. Intell. Eng. 15, 13-24.

Vasconcellos, M., Mackinson, S., Sloman, K., Pauly, D., 1997. The stability of trophic mass-balance models of marine ecosystems: a comparative analysis. Ecol. Model. 100, 125-134.

Van Pagee, J.A., Glas, P.C.G., Markus, A.A., Postma, L., 1988. Mathematical modelling as a tool for assessment of North Sea pollution. In: Salomons, W., Bayne, B.L., Duursma, E.K., Förstner, U. (Eds.), Pollution of the North Sea, An Assessment. Springer-Verlag, Berlin, pp. 400-424. 
Villars, M.T., 1997. Report of the ASMO Workshop on Eutrophication Modelling. Delft Hydraulics Report T1608. Veldhuis, M.J.W., Colijn, F., Venekamp, L.A.H., 1986. The spring bloom of Phaeocystis pouchetii (Hyptophyceae) in Dutch coastal waters. Neth. J. Sea Res. 20, 37-48.

Verkhozina, V.A., Kozhova, O.M., Kusner, Y.S., 2000.

Hydrodynamics as a limiting factor in the Lake Baikal ecosystem. Aquat. Ecosyst. Health Manage. 3, 203-210.
Wortmann, J., Hearne, J.W., Adams, J.B., 1997. Evaluation of effects of freshwater inflow on the distribution of estuarine macrophytes. Ecol. Model. 106, 213-232.

Wootton, J.T., 2001. Local Interactions predict large-scale patterns in empirically derived cellular automata. Nature 413, 841-844.

Wu, F., 1996. A linguistic cellular automata simulation approach for sustainable land development in a fast growing region. Comput., Environ. Urban Syst. 20, 367-387. 